\title{
Currency Flow in an Economy: India's Demonetarization Event
}

\author{
Frederick Betz, Timothy R. Anderson, Aurobindh Kalathil Puthanpura \\ Portland State University, Portland, Oregon, USA \\ Email: fbetz@venture2reality.com
}

How to cite this paper: Betz, F., Anderson, T.R. and Puthanpura, A.K. (2018) Currency Flow in an Economy: India's Demonetarization Event. Theoretical Economics Letters, 8, 476-484

https://doi.org/10.4236/tel.2018.83033

Received: December 28, 2017

Accepted: February 11, 2018

Published: February 14, 2018

Copyright $\odot 2018$ by authors and Scientific Research Publishing Inc. This work is licensed under the Creative Commons Attribution International License (CC BY 4.0).

http://creativecommons.org/licenses/by/4.0/ (c) (i) Open Access

\begin{abstract}
In a previous paper, we analyzed an economic event in 2016-17 of a sudden demonetarization of India, to test the empirical validity of the Chartalist school of monetary theory [1]. The Chartalist school had distinguished three kinds of money: Fiat, Commodity, and Managed Money. The demonetarization event provided empirical evidence for this currency distinction being significant and empirically valid, in the context of the nation of India. That sudden withdrawal of Fiat money immediately decreased the amount of Commodity money, creating an economic crisis in local Indian commerce. Managed Money (as bank accounts) was unable to fill the temporary gap in the supply of money, because a large portion of the Indian population did not have bank accounts. Also the government had not supplied a sufficient number of new Fiat money (new 500 and 2000 rupee notes) to quickly replace the withdrawn 500 and 1000 rupee notes. Our analysis showed that the policy thinking behind the demonetarization event lacked a proper understanding of valid monetary theory. In this paper, we continue the analysis of the demonetarization event by constructing a model of monetary flow in India. This model builds upon the Chartalist theory of money and may help fiscal policy makers to make sound decisions about currency and credit in a nation.
\end{abstract}

\section{Keywords}

Economics, Monetary Theory, Fiscal Policy

\section{Introduction}

The model of the flow of currency within an economy should trace the flow between the public and private sectors, because fiat money is created in the public sector. As L Randall Wray wrote: "It is often useful to distinguish among different types of sectors in the e conomy. The most basic distinction is between the 
public sector (including all levels of government) and the private sector (including households and firms)" [2]. Wray also proposed to use an "accounting balance-sheet" approach between public and private sectors of a national economy [2].

The flow of "fiat money" in a national economy can flow between public and private sectors. And Wray's accounting model for a two-sector economy (private and public) is that fiat money is issued by the government for the function of collecting taxes. Issued fiat money enters the private sector from government spending (purchasing something from the private sector); and returns to the government sector by taxes on the private sector. To trace currency flows between public and private sectors, we construct a system-graphic model of a Chartalist monetary system, as shown in Figure 1. In the public sector of a modern economy, we indicate three functional components: a government treasury, a national central bank, and a foreign exchange for the national fiat currency.

In a model of the private sector, we distinguish between households, companies, and commercial banks. Households, companies, and commercial banks pay taxes into the treasury of the government, in the connective lines of fiat money (solid lines). From the government, this taxed fiat money enters back into the private sector by government purchases (paid by the treasury as expenditures in the treasury account of the central bank). Currency, in the form of managed money (dotted lines), also leaves the public sector of the central bank into the private sector as reserve accounts by commercial banks held in the central bank. Price of this government credit to commercial banks is controlled by the discount rate offered by the central bank.

In accordance with Chartalist monetary theory, money goes from the private sector into the public sector as taxes paid in fiat money. In contrast, money goes from the public into the private sector as 1) government purchases using fiat money and 2) as government credit in the form of managed money in central bank providing credit to commercial banks (at the "discount window" of the

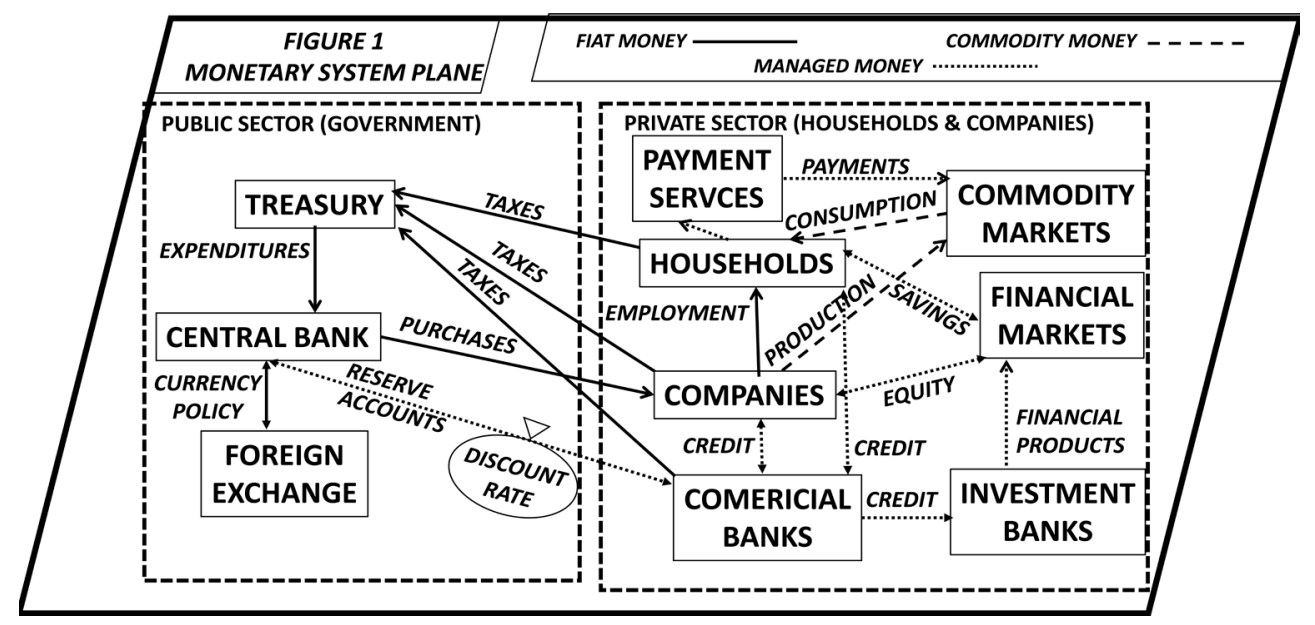

Figure 1. Monetary system plane. 
central bank). As in the Chartalist Modern Money Theory (MMT), this model distinguishes money between the public and private sectors as both printed currency (fiat money) and managed money (credit). Wray emphasized that these two forms of money, between the two sectors, enable the government to increase or decrease money in the economy through the control of the price of bank credit, without having to print or withdraw fiat money from the private sector [2].

Also in the private sector when companies provide employment to households, currency flows as fiat money and as managed money between companies and households. Money also flows between commercial banks and companies and households in the form of credit. Households and companies also interact monetarily with commodity markets in the form of production and consumption of commodity goods (often paid by payment services as Managed money). Money flows in consumption and production by enabled trade in the currency form of commodity money. Commodity money is composed of both fiat money (printed currency) and managed money (bank and payment services accounts). Fiat money is 'good' commodity money; while inflated fiat money is 'bad' commodity money.

To provide equity for companies and savings for households, both companies and households monetarily interact with financial market. Investment banks create and maintain financial markets through financial products, often financed with credit from commercial to investment banks (as managed money).

In modern monetary theory (MMT), Wray also emphasized the use of accounting techniques to describe the actions of a central bank. Wray wrote: “... banks clear accounts among themselves by using central bank reserves. This leads to ... "pyramiding" in modern economies leverage liabilities ... all roads (monetary flows) lead back to the central bank-the sovereign's own bank ... The balance sheet looks more or less like this: $\mathrm{L} 1+\mathrm{L} 2=\mathrm{A} 1+\mathrm{A} 2+\mathrm{A} 3+\mathrm{A} 4+\mathrm{A} 5-$ L3 - L4 - L5" [1]. We use this accounting equation in our monetary system model, putting it into the Institutional component of a central bank (Figure 2).

This equation in the Central Bank is called its accounting balance at a given time. The quantity $(\mathrm{L} 1+\mathrm{L} 2)$ expresses "Reserves" currently held by the Central

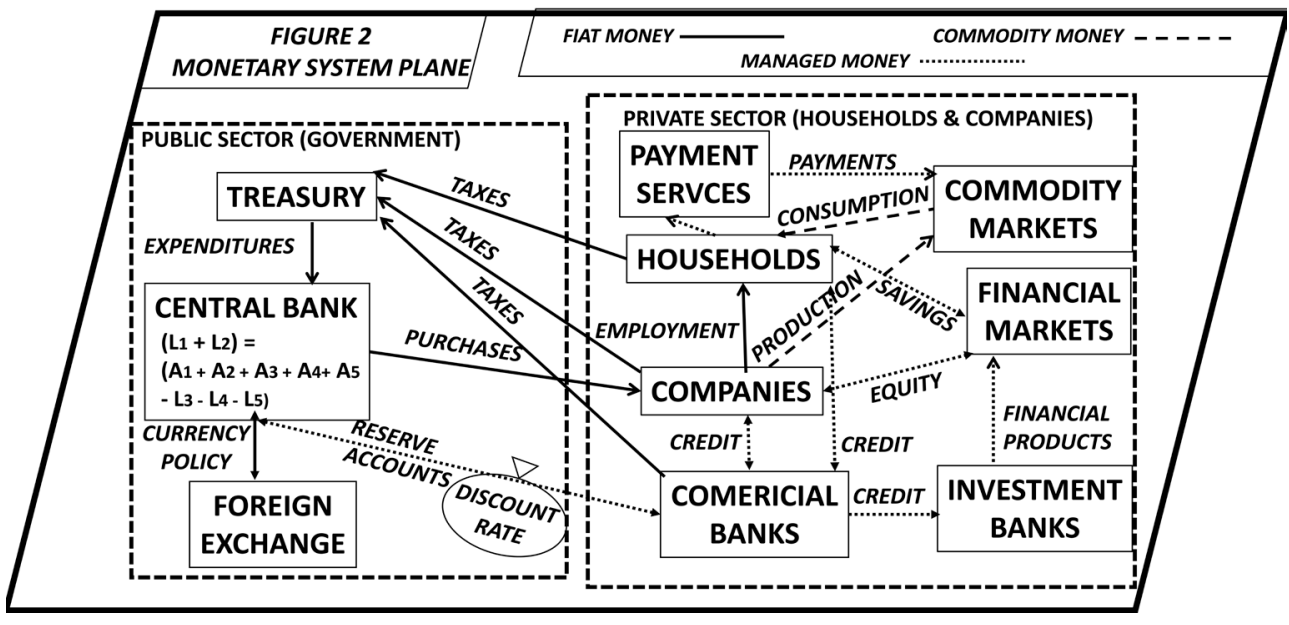

Figure 2. Monetary system plane. 
Bank, with L1 being the vault cash and cash in circulation (central bank notes held by banks and the public) and L2 being the reserve balances of bank accounts held by the central bank. This balance can be altered by actions in the central bank to increase assets or decrease assets. For example, when a central bank buys securities, such as treasury bonds or corporate bonds in a bond market, its asset of A1 increases. When the central bank advance federal funds to other private banks' reserve accounts (through the so-called "Discount Window Operation"), then it's assets of A2 increases. When a central bank buys gold, its asset of A3 increases; when it obtains treasury currency (fiat money) its asset of A4 increases; and when it buys a property, it assets of A5 increases [2].

\section{Currency Flow in the Demonetarization Event of India 2016-17}

In a previous paper, we analyzed the Indian demonetarization event for institutional explanations of the event in the form of societal dynamics depiction of explanations (between key factors in an historical event). And for this event, Figure 3 shows the connections between six dimensions of the societal perceptual space which can provide fifteen kinds of explanations possible in a societal event [1].

The directional controls in any society occur at three levels in the graphic representations of societal explanations: Control in a Managed System, Control in a Socio-Technical System, and Control in a Self-Organizing System. The Managed System in the economic event was the Government of India; the Socio-

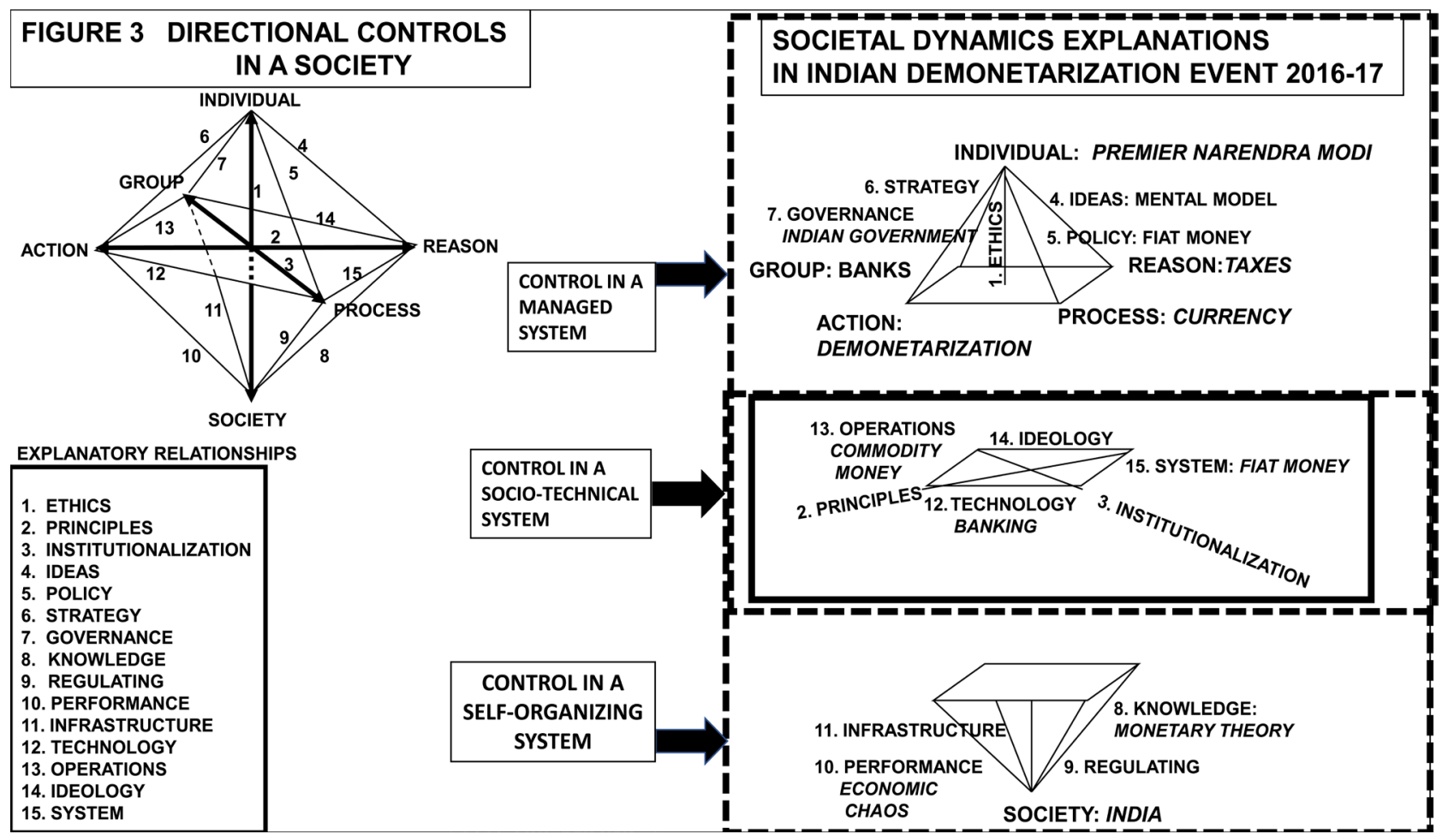

Figure 3. The Directional Controls in a Society. 


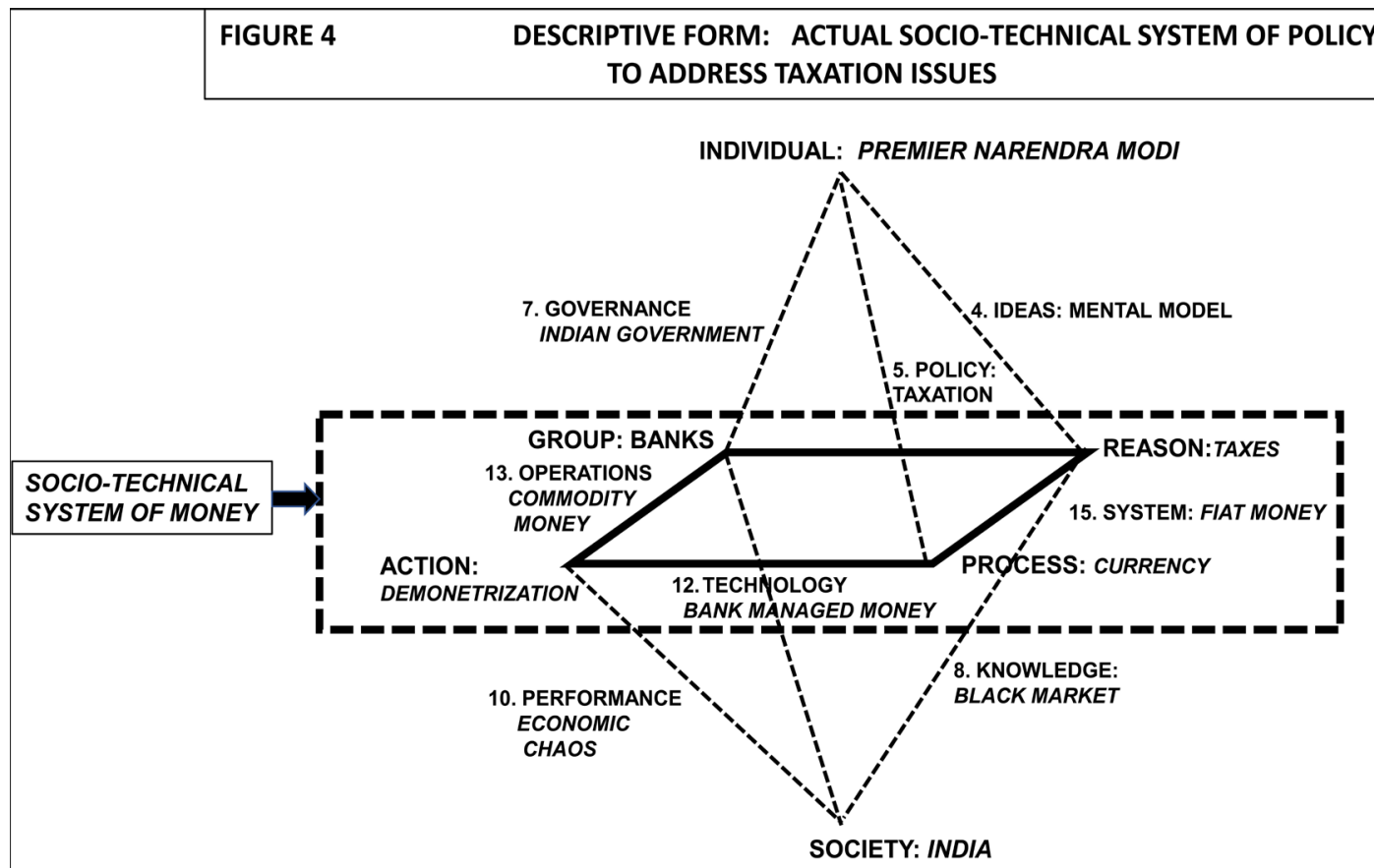

Figure 4. Descriptive form is the "Actual" socio-technical

Technical System was Money; and the Self-Organizing System was the Indian economy. And the demonetarization event, is explained in this analysis as a socio-technical system of money, as shown in Figure 4.

This analysis of the event emphasized that money in the Indian society functioned as a technical system of society (socio-technical system) in the societal Process of Currency. Therein, the two functions of money were as a System of Fiat Money and as an Operation of Commodity Money, which were connected through the Technology of Banking. This way of analyzing the money system highlights how the two functions of money are connected through the Technology of the Banking institutions. But Banking connected the two functions of Currency in only $20 \%$ of the population. The economic chaos resulting from the policy of sudden demonetarization was due to the lack of banking to extend to all the population ( $80 \%$ of the society). The Knowledge of the Mental Model only focused on the cash markets in the economy, Black Market, rather than upon any valid Monetary Theory.

We can now use the currency flow model to see how the System of Fiat money of the government impacted the operations of the commodity money in the currency system, when the government decided to suddenly withdraw 500 and 1000 rupee notes from circulation (in order to catch tax evaders) (Figure 5).

The heavy lines in the model indicate the connections which were most important to the event. The Prime Minister of India intended to increase taxes, which was being paid by only $1 \%$ of the Households, Companies, and Commercial Banks. However, when the Fiat notes of 500 and 1000 rupees were suddenly 


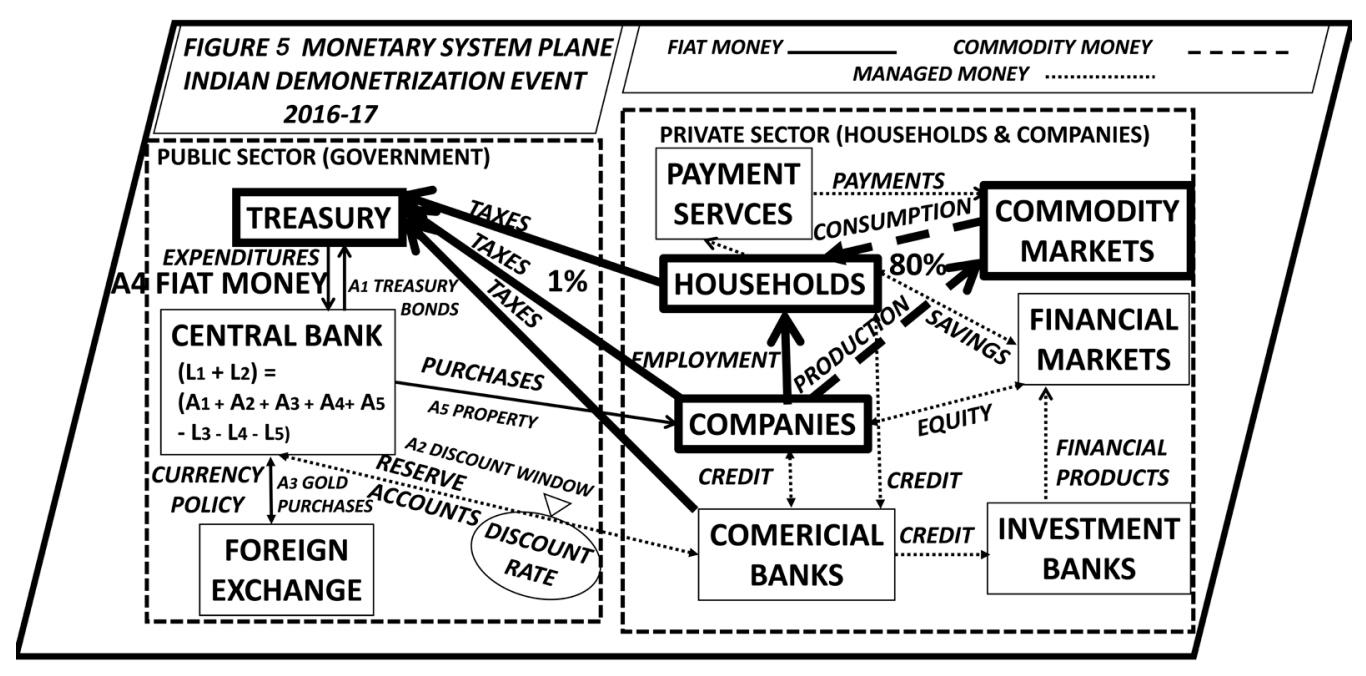

Figure 5. Monetary system plane Indian demonetarization event 2016-17.

withdrawn as legitimate currency by the government, Commodity Markets collapsed, and small Companies (small businesses) laid off employees (Households). Paid for by cash currency, Consumption collapsed, followed by Production.

As indicated by the graphic analysis of monetary flow, the demonetization had significant effect on the economic activity. The GDP during April-June of financial year 2017-18 in fact grew slower at 5.7 per cent, a three year low and 2.2 per cent decline from April-June quarter 2016-17 when it stood on 7.9 per cent [3]. The effect was predicted by former Prime Minister Manmohan Singh, in the Rajya Sabha on 24 November 2016 during debate on demonetization. During the debate on demonetization Manmohan Singh said: "My own feeling is that the national income, that is the GDP, can decline by about 2 per cent as a result of what has been done. This is an underestimate, not an overestimate. Even those who say this measure (demonetization) will do no harm or will cause distress in the short run, but is in the interest of the country in the long run, I am reminded of John Keynes, who once said "In the long run, we are all dead" [4].

Some of the Demonetarized Fiat Money was exchanged at banks and sent on to the Central Bank. The central bank said: "Subject to future corrections based on verification process when completed, the estimated value of the banned notes it received was Rs. 15.28 trillion. This compares with the Rs 15.44 trillion of the banned notes that were in circulation as of November 8 , according to data given by minister of state for finance Arjun Meghwal to Parliament on January 21" [3].

For the Fiat Money in circulation, the value of banknotes declined by $20.2 \%$ from the end of 2016 through 2017 (from Rs. 16,415 to Rs. 13,102 billion at March 2017). The volume of banknotes, however, increased by 11.1 per cent, mainly due to higher infusion of banknotes of lower denomination in circulation following the demonetization. In value terms, the share of 500 and above banknotes, which had together accounted for 86.4 per cent of the total value of banknotes in circulation at end-March 2016, stood at 73.4 per cent at end-March 
2017. The share of newly introduced Rs. 2000 banknotes in the total monetary value of banknotes in circulation was 50.2 per cent at end-March 2017. In volume terms, Rs. 10 and Rs. 100 banknotes constituted $62.0 \%$ of total banknotes in circulation at end-March 2017 as compared with 53.0\% at end-March 2016. In terms of monetary value, the banknotes constituted $22.0 \%$ of total banknotes in circulation at end-March 2017 as compared with 11.5 percent at end-March $2016[5]$.

Figure 6 shows the currency in circulation from October 7th 2016 till November $3^{\text {rd }} 2017$.

In the first two months of the demonetarization event, currency declined by $50 \%$. During the week of November $4^{\text {th }} 2016$, the money circulation was at its peak at Rs.17977.00, just days before the demonetization was announced. There was a steady decline in the money circulation-as the 500 and 1000 rupee notes were no longer legal tender and people had until $30^{\text {th }}$ December 2016 to exchange the old notes for new. The decline in circulation continued until 1st January, 2017. Then the circulation improved each week. As of 3rd November 2017, the money in circulation stood at Rs. 16384.86. Comparing money in circulation from November 2016 to 2017 there was a 50\% drop in the circulation from the previous period.

In Figure 7, we use data from the Reserve Bank of India (RBI) to include an accounting "balance" form in the currency model for India (during the event). In the India's central bank, RBI, reserve money is the highly liquid component of money stock in the economy and plays a crucial role in the determination of other monetary aggregates [6] [7] [8]. Reserve money broadly reflects the total monetary

\section{Currency in Circulation}

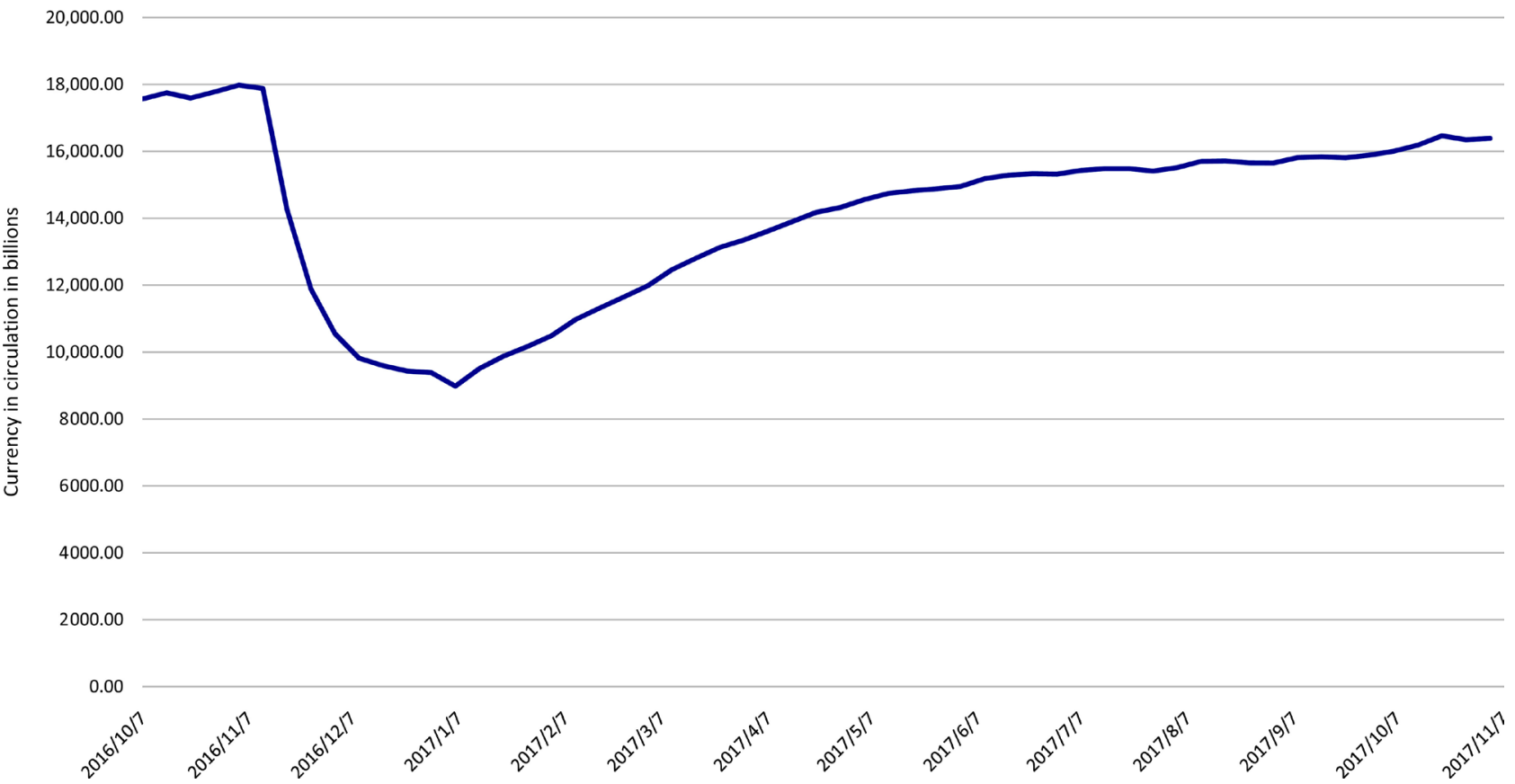

Figure 6. Currency in circulation. 


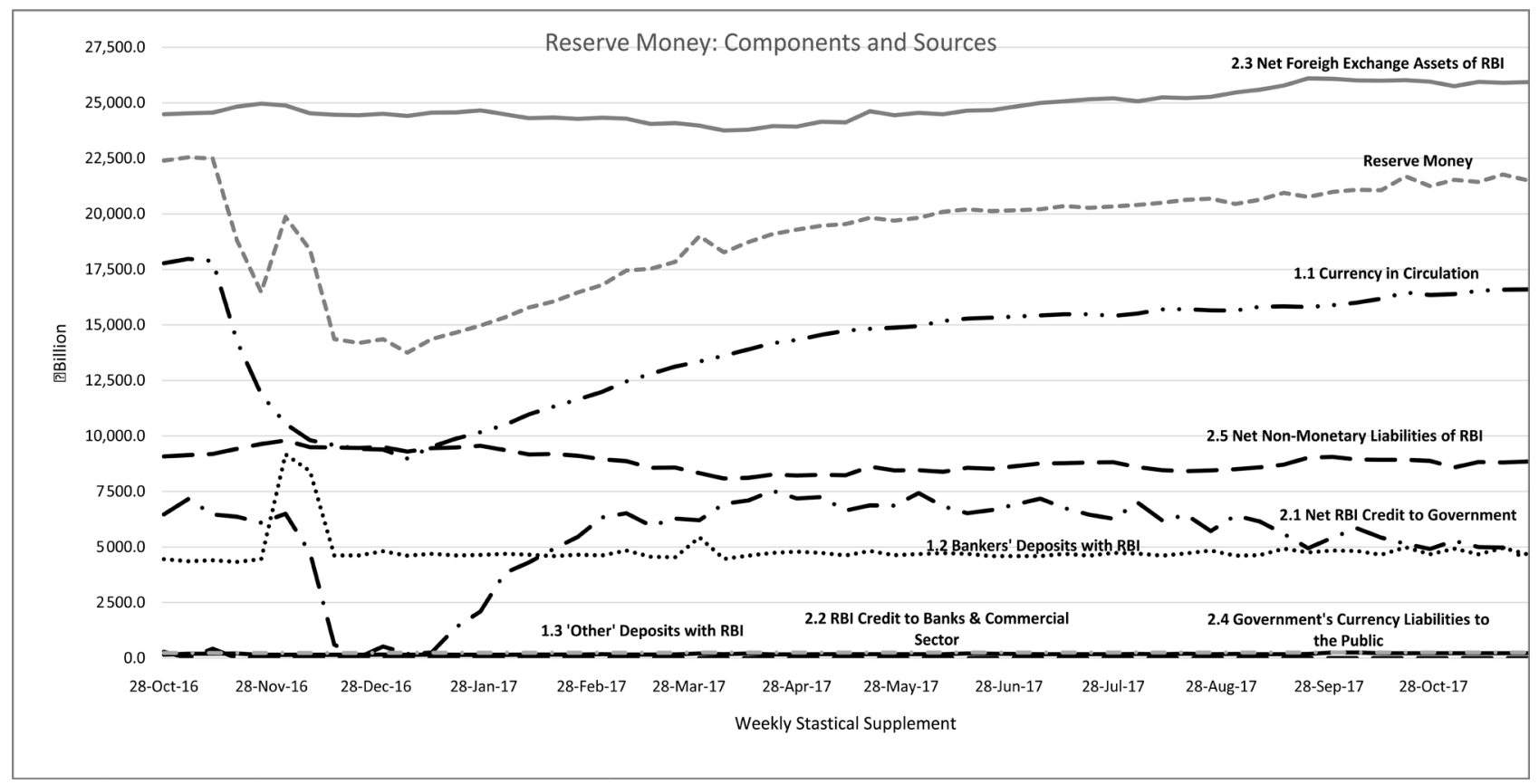

Figure 7. Reserve money: components and sources.

liabilities of the Reserve Bank. The changes in reserve money could be attributed to changes in the balance sheet either in the asset or liability side caused by monetary policy actions and market operations of the Reserve Bank.

The component side of the reserve money is calculated by summing currency in circulation: Bankers' deposit with the RBI and Other deposits with the RBI. The source side of the reserve money is calculated by summing Net RBI credit to the Government, RBI's claims on banks, RBI credit to the commercial sector, RBI's net foreign assets and Government's currency liabilities to public and subtracting RBI's net non-monetary liabilities. Figure 7 also shows the weekly components and sources of reserve money from $28^{\text {th }}$ October 2016 to $24^{\text {th }}$ November 2017.

The source of the data is from the RBI website [8].

L1 is 1.1 Currency in Circulation;

L2 is 1.2 Banker's Deposits with RBI;

L3 is 1.3 'Other' Deposits with RBI;

$\mathrm{L} 1+\mathrm{L} 2$ + L3 are Reserves held by RBI - Reserve Money;

A1 is treasury bonds held by RBI -2.1 Net RBI Credit to Government;

A-2 is private banks reserve accounts - 2.2 RBI Credit to Banks \& Commercial Sector;

\section{A-3 is 2.3 Net Foreign Exchange Assets of RBI.}

The reserve money declined from approximately Rs 22,000 billion before the demonetization event to approximately Rs 14,000 billion, in span of less than 2-months and then slowly increased from its lowest. The decline in reserve money was primarily due to the withdrawal of 500 and 1000 rupee notes as these made the bulk of the component side. There is a spike in the reserve money 
component before it reaches its lowest point. This was due to the increase in the Bankers' deposit with RBI component. The average value has been approximately Rs. 4600 billion. However, during the spike period, the values have been Rs. 9172 and Rs. 8419.5 billion respectively. It had taken over a year for the reserve money component to reach its pre-demonetization level since the major component is currency in circulation. This even impacted the liquidity in the economy, which is one major factor for economic growth.

\section{Summary}

Although this graphic analysis was informed by the empirical example of the Indian Demonetarization Event, the model is general. Its graphic form can help explain other empirical events in monetary policy and in other nations.

\section{References}

[1] Frederick, B., Anderson, T.R. and Puthanpura, A.K. (2017) Modeling Currency Flow in an Economy: The Case of India's Demonetarization in 2016. Theoretical Economics Letters, 7.

[2] Wray, R. (2015) Modern Money Theory. 2nd Edition, Palgrave Macmillan. https://doi.org/10.1057/9781137539922

[3] http://www.hindustantimes.com/business-news/rbi-says-99-of-demonetised-rs-500 -rs-1000-returned-to-banking-system-after-pm-modi-s-surprise-move/story-jPFYd NpNw5nuEYcFNunknI.html

[4] https://www.outlookindia.com/website/story/when-manmohan-singhs-prediction-o n-the-effect-of-demonetisation-on-gdp-came-true/301066

[5] https://rbidocs.rbi.org.in/rdocs/AnnualReport/PDFs/RBIAR201617_FE1DA2F97D6 1249B1B21C4EA66250841F.PDF

[6] Reserve Bank of India-Database on Indian Economy. https://dbie.rbi.org.in/DBIE/dbie.rbi?site=home

[7] Reserve Bank of India-A Handbook on RBI's weekly Statistical Supplement. https://dbie.rbi.org.in/DBIE/doc/Handbook_to_WSS_Final.pdf

[8] Reserve Bank of India-Weekly Statistical Supplement. https://rbi.org.in/Scripts/WSSViewDetail.aspx?TYPE=Section\&PARAM1=8 